\title{
Desenvolvimento de Sequência Didática com a UTILIZAÇÃO DO GEOPLANO NO ENSINO DE FIGURAS PLANAS NA $1^{\text {a }}$ SÉRIE do ENSINO MÉdIO
}

\author{
DEVELOPMENT OF DIDACTIC SEQUENCE WITH THE USE OF GEOPLANE IN \\ THE TEACHING OF FLAT FIGURES IN THE 1ST GRADE OF HIGH SCHOOL
}

DOI: 10.23926/RPD.2526-2149.2020.v5.n2.p582-607.id671

\section{Luciene Costa Santos \\ Especialista em Educação \\ Matemática (UFT) \\ Professora no Colégio \\ Estadual Joana Batista \\ Cordeiro \\ lucienec.santos@hotmail.co \\ $\underline{\mathrm{m}}$}

\section{Alan Santos Gois \\ Doutorando em Matemática \\ Aplicada (UNB) \\ Professor no Instituto \\ Federal de Goiás (IFG) \\ alan.gois@ifg.edu.br}

\section{Dailson Evangelista \\ Costa}

Doutorando em Educação

em Ciências e Matemática

(UFMT).

Professor na Universidade

Federal do Tocantins (UFT).

dailson_costa@uft.edu.br

\section{Tadeu Oliver \\ Gonçalves}

Doutor em Educação

(UNICAMP)

Professor na Universidade

Federal do Pará (UFPA)

Instituto de Educação

Matemática e Científica

(IEMCI)

tadeuoliver@yahoo.com.br
Resumo: O objetivo desta pesquisa é compreender como o desenvolvimento de uma Sequência Didática no processo de ensino e aprendizagem de figuras planas, com o auxílio do material didático Geoplano, contribui para a construção do conhecimento matemático do educando. Para tanto, adotamos uma abordagem qualitativa e utilizamos de orientações teóricas sobre a utilização de materiais didáticos concretos e manipuláveis. Construímos e apresentamos uma Sequência Didática contendo 12 (doze) atividades investigativas voltadas para a aprendizagem de figuras planas a partir do uso do material didático Geoplano. A Sequência Didática foi desenvolvida no Colégio Estadual Professora Joana Batista Cordeiro, no município de Arraias (TO), em uma turma de $1^{\mathrm{a}}$ série do Ensino Médio, composta por 24 alunos. Utilizamos também um questionário com 6 (seis) perguntas abertas sobre o material didático Geoplano. Os resultados da pesquisa apontam que o material didático Geoplano é um facilitador no processo de ensino e aprendizagem de Matemática de forma lúdica e prazerosa.

Palavras-chave: Figuras planas. Sequência Didática. Geoplano

\begin{abstract}
The objective of the research is to understand how the development of a Didactic Sequence in the teaching and learning process of flat figures, with the help of the Geoplane didactic material, contributes to the construction of the student's mathematical knowledge. For this, we adopt a qualitative approach and use theoretical guidelines on the use of concrete and manipulable teaching materials. We built and presented a Didactic Sequence containing 12 (twelve) investigative activities aimed at learning flat figures from the use of the Geoplane didactic material. The Didactic Sequence was developed at the Colégio Estadual Professora Joana Batista Cordeiro, in the city of Arraias (TO), in a class of 1st grade of High School, composed of 24 students. We also used a questionnaire with 6 (six) open questions about the Geoplane teaching material. The research results show that the Geoplane teaching material is a facilitator in the process of teaching and learning mathematics in a playful and enjoyable way.
\end{abstract}

Keywords: Flat figures. Following teaching. Geoplane 


\section{INTRODUÇÃO}

O ensino e a aprendizagem da Matemática, há muitos anos, vêm sendo considerado difícil e desinteressante para os alunos. As chamadas aulas tradicionais de Matemática não despertam o interesse e a curiosidade dos estudantes, chegando ao ponto de D'Ambrosio (1991, 2009) dizer que são inúteis, desinteressantes e obsoletas. E o professor que continuar exercendo a sua profissão como transmissor de conhecimento está fadado ao fracasso, afirma o referido autor. Dessa forma, faz-se necessário repensar metodologias e estratégias a serem desenvolvidas em sala de aula, de forma a possibilitar a formação de sujeitos ativos na construção do seu próprio conhecimento. As atividades práticas podem ser uma excelente alternativa para diminuir esse impasse e proporcionar uma aula que possa ser interessante, atrativa e que possibilite ao aluno a construção do conhecimento matemático. Assim, as atividades práticas de Matemática devem proporcionar um pensamento ativo que instigue a construção do conhecimento através de processos lógico-interrogativos (MENDES, 2009). O aluno ao desenvolver atividades práticas pode interagir com os objetos em seu entorno e despertar a criação do campo imaginativo (LORENZATO, 2006; BITTAR; FREITAS, 2005).

Com o intuito de buscar mecanismos que contribuam com essa perspectiva, apresentamos nesta pesquisa uma Sequência Didática, construída por nós, utilizando o material didático Geoplano no processo de ensino e aprendizagem de figuras planas. Acreditamos que propostas como esta que apresentamos e desenvolvemos com alunos do Ensino Médio são fundamentais nas aulas de Matemática.

As Tendências metodológicas em Educação Matemática, tais como: Jogos e Materiais Concretos, Etnomatemática, Resolução de Problemas, Modelagem Matemática, Tecnologias da Informação e Comunicação, Didática da Matemática, História da Matemática, Linguagem Matemática e Educação Matemática Crítica, aliadas à postura e abordagem investigativa, são alternativas que podem melhorar os processos de ensino e de aprendizagens nas aulas de Matemática (DIAS, 2016; FLEMMING; LUZ; MELLO, 2005; MENDES, 2009). Com vistas a essas possibilidades é que o material didático Geoplano foi apresentado como um instrumento facilitador, particularmente com vistas aos processos de ensino e de aprendizagens de perímetro, área e ângulo de figuras planas.

O Geoplano, material didático criado pelo matemático inglês Caleb Gattegno, do Institute of Education, London University, consiste numa prancha com pinos e elásticos, usados para representar formas geométricas no plano (TIGGERMANN et al, 2013; COSTA; PEREIRA; MAFRA, 2011; MENEZES, 2008). O Geoplano possibilita criar um contexto de 
ensino e aprendizagem em sala de aula, através da resolução de problemas, levantamento de conjecturas e hipóteses, em que o aluno interage com situações desafiantes, dialoga com os elementos do problema, manuseia e cria soluções.

Com base nessas informações, definimos nossa questão de pesquisa da seguinte maneira: Em que aspectos o desenvolvimento de Sequência Didática no processo de ensino e aprendizagem de figuras planas, com o auxílio do material didático Geoplano, pode contribuir para a construção do conhecimento matemático do educando? Com a intenção de responder esta pergunta objetivamos compreender como o desenvolvimento de uma Sequência Didática no processo de ensino e aprendizagem de figuras planas, com o auxílio do material didático Geoplano, contribui para a construção do conhecimento matemático do educando.

Este trabalho se configura como uma pesquisa de campo, pois segundo Fiorentini e Lorenzato (2012, p. 71), em uma pesquisa de campo "a coleta de dados é realizada diretamente no local em que o problema ou fenômeno acontece e pode dar-se por amostragem, entrevista, observação participante, pesquisa-ação, aplicação de questionário e testes". Para tanto, adotamos uma abordagem qualitativa em conformidade com as considerações de Ludke e André (1986), cujos dados coletados são descritos e a preocupação com o processo é muito maior do que com o produto. Para contribuir na análise do material empírico produzido, utilizamos, além da observação direta dos pesquisadores, a aplicação de um questionário com perguntas abertas. Sobre isso, Fiorentini e Lorenzato (2012, p. 116) afirmam que questões abertas "não apresentam alternativas para respostas, podendo o pesquisador captar alguma informação não prevista por ele ou pela literatura".

A pesquisa foi desenvolvida no Colégio Estadual Professora Joana Batista Cordeiro, Escola em Tempo Integral, no município de Arraias (TO). As informações sobre a escola campo da pesquisa foram retiradas do Plano de Ação da Escola, cujo princípio é a formação de jovens autônomos, solidários e competentes, por meio da construção dos seus Projetos de Vida e do Protagonismo Juvenil, contando com a participação ativa da comunidade, familiares e parceiros. Esse modelo de escola adota em seu currículo 6 (seis) aulas de Matemática e 1 (uma) aula de prática de Matemática, semanalmente. O desenvolvimento da Sequência Didática com o Geoplano ocorreu em 6 (seis) aulas com 24 (vinte e quatro) alunos em uma turma de $1^{\text {a }}$ série do Ensino Médio.

Para a composição teórica apresentamos uma discussão sobre o uso de materiais didáticos concretos e manipuláveis no processo de ensino e aprendizagem de Matemática. Além disso, tratamos do conceito de Sequência Didática na perspectiva de vários autores e abordamos 
uma discussão sobre o Geoplano. Assim, buscamos nos fundamentar, principalmente, nos seguintes autores: D’Ambrosio (2009), Fiorentini e Lorenzato (2012), Knijnik, Basso e Klusener (1996), Lorenzato (2006), Mendes (2009), Tiggemann (2013) e Zabala (1998).

\section{MATERIAIS DIDÁTICOS CONCRETOS E MANIPULÁVEIS}

A Educação Matemática é uma área de conhecimento das ciências sociais ou humanas e busca investigar e produzir conhecimentos sobre os fenômenos e problemas relacionados ao processo de ensino e aprendizagem de Matemática e à formação do professor que ensina Matemática. Assim, a Educação Matemática deve envolver o domínio do conteúdo de Matemática e dos processos pedagógicos apropriados para a construção do saber matemático (FIORENTINI; LORENZATO, 2012; MENDES, 2009; MATOS; SERRAZINA， 1996; D’AMBROSIO, 2009).

O uso de materiais concretos e jogos no ensino de Matemática é uma alternativa que pode contribuir de forma positiva e significativa. As atividades desenvolvidas com o uso desses recursos propiciam a redescoberta pelo aluno e contribui na construção do seu conhecimento matemático. Para Reys (1971, apud MENDES, 2009) esses materiais devem ser tocados, sentidos, manipulados e movimentados pelos alunos. Podem ser materiais do cotidiano como: balança, trena, fita métrica e outros confeccionados como Ábaco, Blocos Lógicos, Tangram, Geoplano. Os materiais concretos podem ser construídos pelos alunos, onde poderão elaborar regras e testá-las, estimulando a criatividade, o desenvolvimento do raciocínio lógico e a compreensão de conceitos matemáticos.

O uso de materiais didáticos concretos e manipuláveis nas aulas foi defendido por muitos educadores ao longo da história que ressaltaram a importância do apoio visual ou do visual-tátil para o processo de ensino e aprendizagem. Destacaremos as suas contribuições em defesa da utilização de materiais didáticos concretos e manipuláveis no processo de ensino e aprendizagem.

As pesquisas realizadas por Lorenzato (2006), Fiorentini e Miorim (1990), Nacarato (2005), Rêgo, Rêgo e Vieira (2012), Rodrigues e Gazire (2015), Varizo e Civardi (2011), evidenciam que o uso de materiais didáticos concretos e manipuláveis foi defendido por vários pesquisadores, filósofos, psicólogos, matemáticos e educadores ao longo da história, por revelarem a importância da utilização destes tipos de materiais como recursos didáticos auxiliadores no processo de ensino e aprendizagem de Matemática. 
Por volta de 1650, Comenius defendeu que o ensino deveria acontecer do concreto ao abstrato, que o conhecimento começa pelos sentidos e que só se aprende fazendo. Em 1680, Locke ressaltou a necessidade de experiência sensível para alcançar o conhecimento. Por volta de 1780, Rousseau recomendou experiência direta com objetos, visando a aprendizagem. Em 1800, Pestalozzi e Froebel reconheceram que o ensino deveria começar pelo concreto. Por volta de 1900, Dewey ressaltou a importância do material concreto para a construção do conhecimento e Poincaré recomendou o uso de imagens vivas para explicar verdades matemáticas. Posteriormente, Montessori apresentou exemplos de materiais didáticos e atividades de ensino que valorizam a aprendizagem por meio dos sentidos. Piaget argumentou que o conhecimento acontece pela ação refletida sobre o objeto. Vygotsky e Bruner defenderam que experiências reais contribuem para a construção do raciocínio lógico das crianças (LORENZATO, 2006; FIORENITNI; MIORIM, 1990; RODRIGUES; GAZIRE, 2015; VARIZO; CIVARDI, 2011). Muitos foram os educadores que evidenciaram o fundamental papel do material didático no desempenho da aprendizagem, além dos citados caberiam outros que também foram relevantes na defesa dos materiais didáticos como apoio nas aulas de Matemática. Concordamos com essa necessidade evidenciada pelos autores supracitados e pelos defensores ao longo da história. Acreditamos que o uso de material didático pode contribuir para a melhoria do ensino e da aprendizagem de Matemática.

Para Lorenzato (2006), Material Didático (MD) “é qualquer instrumento útil ao processo de ensino e aprendizagem, pode ser um giz, uma calculadora, um filme, um livro, um quebra-cabeça, um jogo, uma embalagem, uma transparência”. Ressaltamos que quando estes materiais são utilizados como auxiliar em qualquer atividade que visa o processo de ensino e aprendizagem são considerados materiais didáticos, uma vez que o termo didático está relacionado a uma intencionalidade em ensinar algo a alguém. Além disso, é pertinente destacar que caso estes materiais, ou qualquer outro, não sejam utilizados como auxiliares no processo de ensino e aprendizagem, são concebidos apenas como um simples material, por exemplo, uma escova de dente, uma cadeira, uma cama etc. Defendemos e acreditamos na utilização de materiais didáticos concretos e manipuláveis como instrumentos auxiliares no processo de ensino e aprendizagem de Matemática, considerando suas intencionalidades didáticas para abordar algum conteúdo ou conceito matemático.

Lorenzato (2006) classifica o MD em estático ou dinâmico. O material didático estático é aquele material concreto que não permite transformação por continuidade, ou seja, não permite alteração em sua estrutura física a partir da sua manipulação, o sujeito apenas manuseia 
e observa o objeto para abstrair algumas propriedades a partir das reflexões realizadas. Exemplos de materiais didáticos estáticos: Blocos Lógicos, Tangram, Geoplano e Sólidos Geométricos. O material didático dinâmico é aquele que permite transformação por continuidade, ou seja, pode ser transformado à medida que é manipulado, auxilia a percepção das propriedades, a conjectura e redescoberta e possibilita uma aprendizagem mais significativa. Exemplos de materiais didáticos dinâmicos: estrela de papel, dobraduras de papel, massa de modelar (LORENZATO, 2006; RODRIGUES; GAZIRE, 2015).

Os MDs podem ter várias funções e serem usados para apresentar um assunto, motivar alunos, auxiliar a memorização e facilitar a redescoberta pelos estudantes. Cabe ao professor ter bem definido a finalidade e intencionalidade quando for trabalhar com MD e escolher o mais conveniente para atingir o objetivo e fazer referência aos conteúdos que ele pretende ensinar. Os MDs são considerados excelentes instrumentos para o aluno construir seu conhecimento matemático, porém o professor precisa saber utilizá-los. Assim, ao utilizar os materiais didáticos, o professor precisa assumir o papel de orientador, planejar sua aula, ter clareza do objetivo que pretende alcançar, utilizar de forma adequada e formular questões que permitam a passagem do concreto ao abstrato por meio de construções racionais (LORENZATO, 2006; RODRIGUES; GAZIRE, 2015). Além disso, o conhecimento teórico e metodológico sobre como utilizar MD no processo de ensino e aprendizagem de Matemática é extremamente necessário.

Quando o uso do MD é novidade para o aluno é importante que o professor deixe um tempo livre para observação, manuseio e exploração do próprio material. No desenvolvimento das atividades é importante que seja realizada a verbalização do pensamento, isto é, que o aluno possa expressar o seu raciocínio, suas ideias e conclusões, que seja uma socialização em grupo, para que as ideias possam se unir na composição do conhecimento matemático. Para isso, o professor precisa propor atividades que proporcionem estas interações e investigações.

Concordamos com Mendes (2009, p. 25) quando afirma que "o uso de materiais concretos, no ensino da Matemática, é uma ampla alternativa didática que contribui para a realização de intervenções do professor na sala de aula durante o semestre letivo". Assim, os materiais concretos se constituem como alternativas metodológicas para as aulas do professor.

Serrazina (1990), ao analisar a utilização de materiais didáticos no ensino da Matemática, observa que deve haver um cuidado especial quando se pretende fazer uso desse recurso, e que, nesse aspecto, o professor tem um papel fundamental. Os materiais didáticos 
devem servir como mediadores para facilitar a relação professor-aluno-conhecimento no momento em que um saber está sendo construído.

Apresentamos a importância do uso de materiais didáticos concretos e manipuláveis, conforme o entendimento de alguns especialistas. Compreendemos a necessidade de utilizá-los nas aulas de Matemática desde que o professor construa atividades de caráter investigativo e seja conhecedor de suas potencialidades e limitações. Dissertaremos, no próximo tópico, sobre a utilização do material didático Geoplano como um instrumento didático que pode contribuir para o ensino e aprendizagem de conteúdos relativos às figuras planas em práticas de sala de aula de Matemática.

\section{Material Didático: GeOPlano}

O Geoplano é um material criado pelo matemático inglês Caleb Gattegno, do Institute of Education da London University, em 1961, e consiste numa prancha com pinos e elásticos usados para produzir formas geométricas no plano. O nome Geoplano é de origem inglesa (geoboards) e francesa (geoplans), onde "geo" vem de geometria e "plans" significa superfície plana (KNIJNIK; BASSO; KLUSENER, 1996; MENEZES, 2008).

Este material possibilita criar um contexto de ensino e aprendizagem em sala de aula, a partir da resolução de problemas, favorecendo o levantamento de conjecturas e hipóteses, onde o aluno irá interagir com situações desafiadoras, dialogar com os elementos do problema, manusear e criar soluções. Concordamos com Cabeb Gattegno (1961) em seu texto " $A$ pedagogia da Matemática", quando defende que:

\footnotetext{
Todos os Geoplanos têm indubitável atrativo estético e foram adotados por aqueles professores que os viram ser utilizados. Podem proporcionar experiências geométricas a crianças desde cinco anos, propondo problemas de forma, dimensão, de simetria, de semelhança, de teoria dos grupos, de geometria projetiva e métrica que servem como fecundos instrumentos de trabalho, qualquer que seja o nível de ensino (GATTEGNO apud KNIJNIK; BASSO; KLUSENER, 1996, p. 5-6).
}

Tradicionalmente, os Geoplanos estão classificados em 3 (três) tipos, no que diz respeito a sua forma, podendo ser: Geoplano retangular, Geoplano circular e Geoplano isométrico. O Geoplano retangular (figura 1) consiste numa prancha retangular com pinos dispostos em linhas e colunas equidistantes. É usado principalmente no ensino de geometria plana e analítica, permitindo a construção de pontos, segmentos de retas e polígonos. O Geoplano circular (figura 2) consiste numa prancha com pinos fixos, dispostos em forma de círculos, a uma mesma distância uns dos outros, e um pino central. É usado em atividades que envolvem ângulos, círculo e circunferência, podendo ser encontrados com vários pinos. Por fim, no Geoplano 
isométrico (figura 3) os pinos não estão dispostos em linhas e colunas, mas de forma alternada. É utilizado no ensino de triângulos e polígonos compostos por triângulos, bem como de outros conteúdos. As potencialidades e alternativas de adaptação e relação entre esses tipos de Geoplanos são variadas. Existem, também, outros tipos de Geoplanos para além destes que apresentamos nesta investigação. Apenas afirmamos que estes são os três tipos, tradicionalmente, conhecidos.

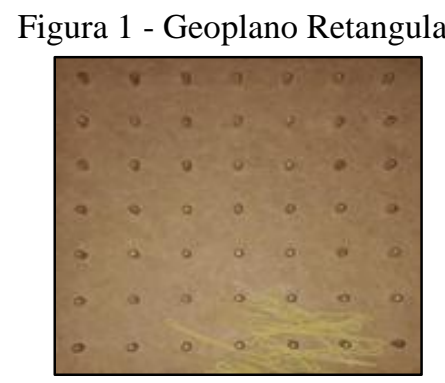

Fonte: Produção nossa
Figura 2 - Geoplano Circular

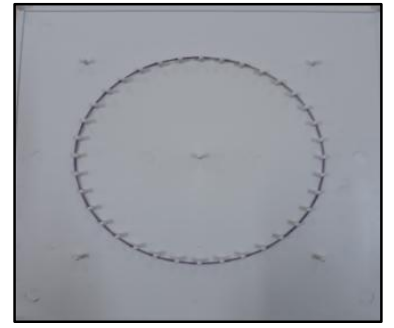

Fonte: Produção nossa
Figura 3 - Geoplano Isométrico

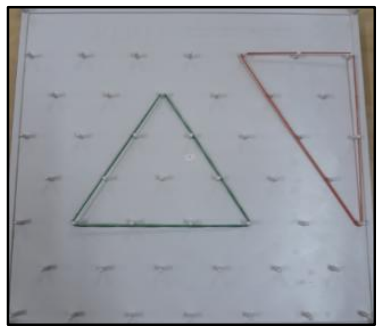

Fonte: Produção nossa

Segundo Machado (2004) o Geoplano é um material didático-pedagógico dinâmico e manipulativo que contribui na exploração de problemas geométricos e algébricos, possibilitando conjecturas e as atividades podem ser desenvolvidas também em papel quadriculado. A forma de construí-los e de apresentá-los varia de acordo com a existência de exemplares confeccionados e industrializados por empresas especializadas, e pode ser confeccionado de diferentes formas e com materiais alternativos.

Para desenvolver as atividades no Geoplano os alunos podem utilizar elásticos coloridos ou barbante. Assim, ao construir as figuras, os alunos poderão conjecturar, levantar hipóteses e construir os seus conhecimentos matemáticos, possibilitando, assim, que o ensino seja atrativo, interativo, facilitando a aprendizagem. Do ponto de vista teórico e metodológico, é muito importante que os estudantes construam os próprios Geoplanos e, nesse processo de construção, estabeleçam relações com alguns conceitos matemáticos necessários para a sua construção.

Acreditamos na importância e necessidade de utilização de material didático concreto e manipulável, particularmente do Geoplano nas aulas de Geometria, porém, defendemos que a utilização de materiais didáticos concretos e manipuláveis precisa de um planejamento de atividades que permitam a articulação entre os conteúdos a serem ensinados, os estudantes, o professor e o material didático como auxiliar do processo de ensino e aprendizagem. Acreditamos que esta articulação pode ser desenvolvida por meio de sequências didáticas construídas, planejadas e utilizadas nas aulas de Matemática. Teceremos, no próximo tópico, 
sobre Sequência Didática e sua importância nas aulas de Matemática com os materiais didáticos.

\section{SEquênCia DidÁtica}

Com base nas abordagens apresentadas nos tópicos anteriores podemos observar que o material didático Geoplano é um material concreto que pode ser utilizado com foco investigativo nas aulas de Matemática, desde que o professor desenvolva uma Sequência Didática investigativa, com atividades sequenciadas, estimulando a construção do conhecimento de forma lúdica.

Zabala (1998, p. 18), no livro A prática educativa: como ensinar, define que "Sequência Didática é um conjunto de atividades ordenadas, estruturadas e articuladas para a realização de certos objetivos educacionais, que tem um princípio e um fim conhecidos tanto pelo professor como pelos seus alunos". O autor ressalta que Sequência Didática é diferente de atividade, sendo esta uma unidade mais elementar que constitui o processo de ensino e de aprendizagem. Uma atividade pode ser uma exposição dialogada, um trabalho prático, uma observação, um estudo, um debate, uma leitura, uma pesquisa bibliográfica, uma tomada de notas, uma ação motivadora, uma aplicação. Já uma Sequência Didática possui uma organização mais complexa que uma atividade. Assim, uma Sequência Didática é um conjunto de atividades ligadas entre si e que possui relações entre elas, e que as atividades tenham intencionalidades didáticas, que seja organizada de forma bem detalhada e explícita, que apresente situações, tarefas e perguntas investigativas, que possibilite os estudantes interagirem entre eles e com o material didático escolhido, que possibilite uma participação do professor como mediado do processo, e que vise uma aprendizagem que parte da própria construção do conceito por parte do aluno até chegar a definição do objeto matemático a ser ensinado.

Zabala (1998) ressalta que quando organizamos atividades em uma série ou sequência significativa, ampliamos a unidade de análise elementar (atividades ou tarefas) para uma nova unidade. Identificamos as sequências de atividades ou sequências didáticas como unidade preferencial para uma análise da prática, permitindo estudar e avaliar sob uma perspectiva processual, incluindo, assim, as fases de planejamento, desenvolvimento e avaliação.

As sequências didáticas propiciam mecanismos favoráveis ao processo de ensino e aprendizagem e que o aluno tem a oportunidade de construir os conhecimentos matemáticos com a mediação do professor. Para Zabala (1998, p. 20 -21): 
As sequências de atividades de ensino/aprendizagem, ou sequências didáticas, são uma maneira de encadear e articular as diferentes atividades ao longo de uma unidade didática. Assim, pois, poderemos analisar as diferentes formas de intervenção segundo as atividades que se realizam e, principalmente, pelo sentido que adquirem quanto a uma sequência orientada para a realização de determinados objetivos educacionais. As sequências podem indicar a função que tem cada uma das atividades na construção do conhecimento ou da aprendizagem de diferentes conteúdos e, portanto, avaliar a pertinência ou não de cada uma delas, a falta de outras ou a ênfase que devemos lhes atribuir. O papel do professor e dos alunos e das relações que se produzem na aula entre professor e alunos ou alunos e alunos, afeta o grau de comunicação e os vínculos afetivos que se estabelecem e que dão lugar a um determinado clima de convivência.

As sequências didáticas são essenciais nas aulas de Matemática, sendo as suas contribuições estudadas sobre uma visão pedagógica, didática e formativa pelos educadores matemáticos. Costa (2013, p. 69-70) definiu Sequência Didática para o Educador Matemático da seguinte maneira:

\begin{abstract}
Sequência Didática é um conjunto/grupo de atividades/tarefas/situações didáticas em ordem crescente de complexidade, sejam elas disciplinares, transdisciplinares ou interdisciplinares, construídas reflexivamente pelo professor que, ao estabelecer relações com o conhecimento pedagógico do conteúdo, institui uma ordenação, estruturação e articulação entre as atividades/tarefas/situações didáticas com as alternativas (tendências) metodológicas da Educação Matemática para a realização de certos objetivos educacionais, que tem um princípio e um fim conhecidos tanto pelo professor como pelos seus alunos.
\end{abstract}

Portanto, uma Sequência Didática deve ser uma ferramenta de trabalho do professor de Matemática, que o auxilie no desenvolvimento do conteúdo a ser ministrado e possibilite o ensino e aprendizagem de forma ativa, interativa, construtiva, participativa e investigativa.

\title{
5 SEQuÊNCIA DidÁtica CONSTRUídA E DESENVOLVIDA
}

Nesta pesquisa, tomamos como ponto de partida a seguinte tarefa: construir uma Sequência Didática para o ensino de figuras planas com o Geoplano para alunos da primeira série do Ensino Médio. Com base nesta tarefa analisamos o currículo do Estado do Tocantins e percebemos que figuras planas fazem parte do bloco matemático intitulado Espaço e Forma. Além disso, definimos os seguintes conteúdos a serem ensinados por meio da Sequência Didática: área, perímetro, ângulos de figuras planas.

A Sequência Didática aqui proposta tem como objetivo geral identificar e explorar os conceitos de perímetro, área e ângulos das figuras planas com o Geoplano. E, como objetivos específicos: utilizar o Geoplano no estudo de perímetro, área e ângulos das figuras planas, além de explorar outros conceitos matemáticos com esse recurso como: ponto, segmento de reta, ponto médio, diagonal, mediana e as características das figuras planas (quadrado, retângulo, triângulo, paralelogramo, losango e trapézio). Os recursos listados necessários foram: Geoplano retangular, elásticos coloridos, papel A4, lápis e borracha. O tempo estimado para o 
desenvolvimento da Sequência Didática foi de 6 (seis) aulas de 50 (cinquenta) minutos cada. A Sequência Didática construída possui 12 (doze) atividades, 23 (vinte e três) tarefas e 178 (cento e setenta e oito) perguntas investigativas.

Quadro 1 - Atividades 1 e 2

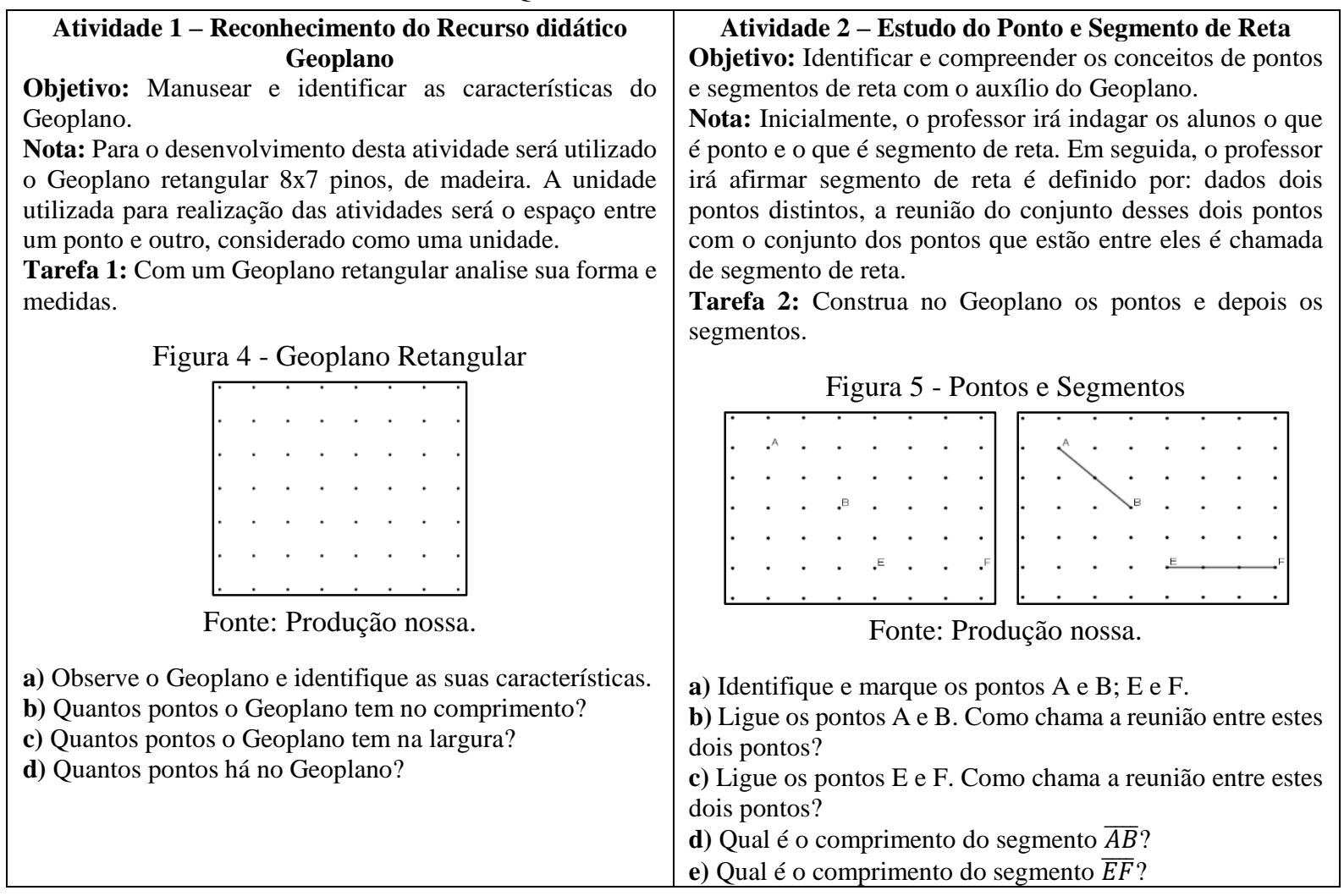

Fonte: Produção nossa

Quadro 2 - Atividades 3 e 4

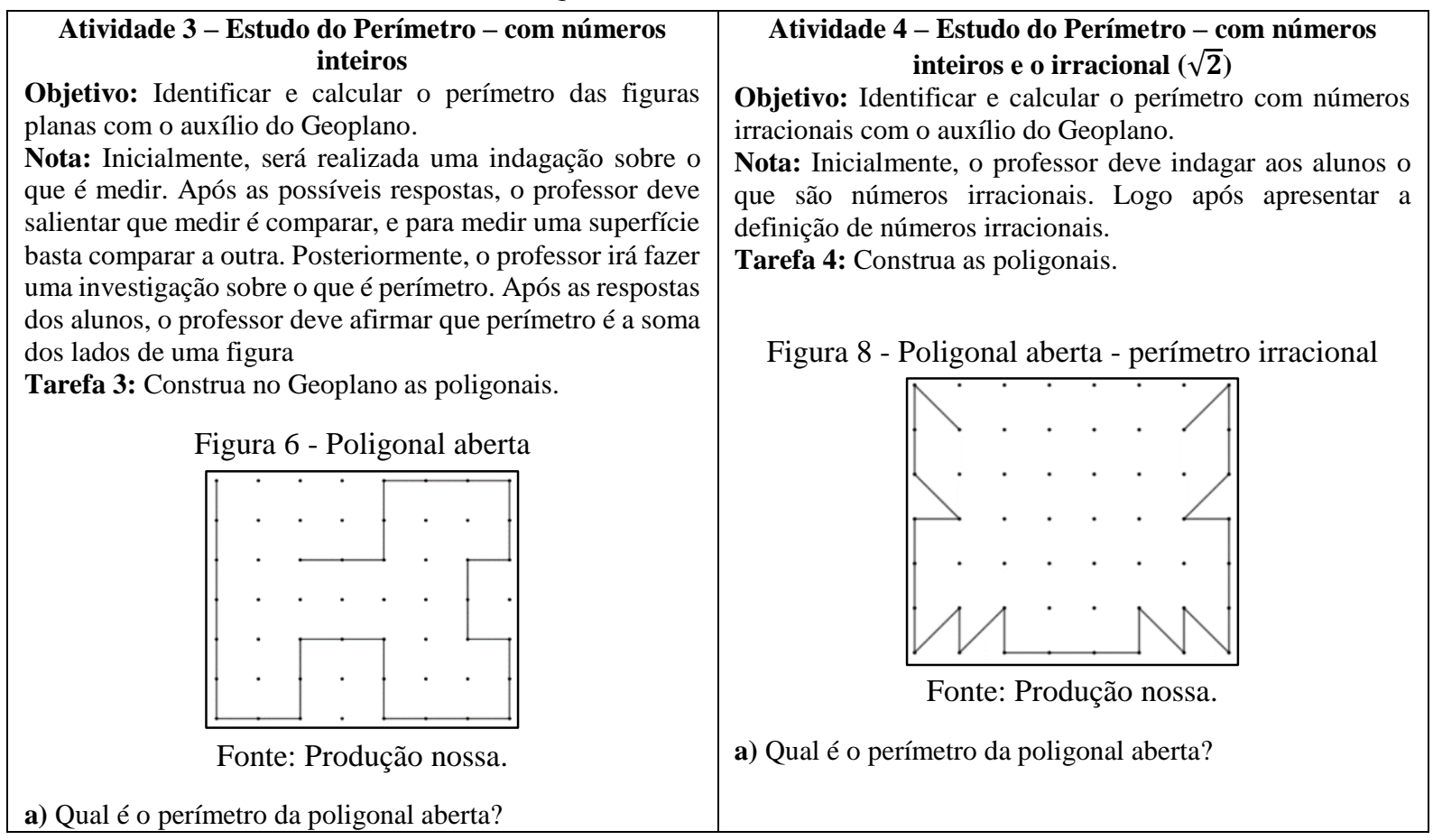


Figura 7 - Poligonal fechada

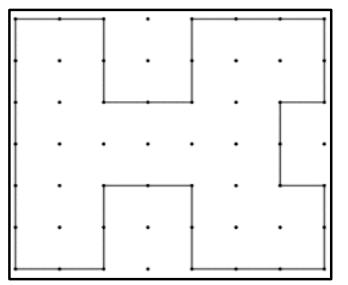

Fonte: Produção nossa.

b) Qual é o perímetro da poligonal fechada?

Figura 9 - Poligonal fechada - perímetro irracional

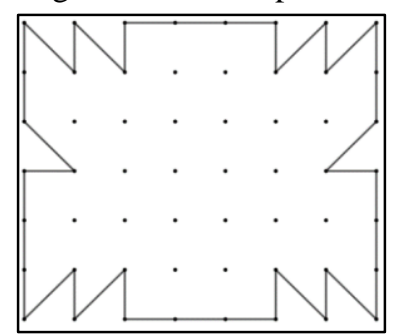

Fonte: produção nossa.

b) Qual é o perímetro da poligonal fechada?

Fonte: Produção nossa.

Quadro 3 - Atividade 5

\section{Atividade 5 - Estudo da Área do Polígono}

Objetivo: Determinar a área dos polígonos a partir de relações com as figuras conhecidas.

Nota: Inicialmente, o professor deve indagar sobre o que é área. Deixar os alunos apresentarem as respostas. Posteriormente, o professor deve intervir afirmando que área é a medida de uma superfície.

Tarefa 5.1: Construa o polígono.

Figura 10 - Polígono

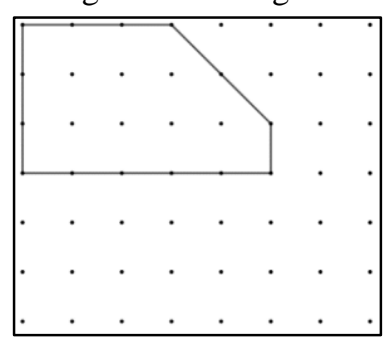

Fonte: Produção nossa.

a) Quantos lados têm este polígono?

b) Qual é o perímetro deste polígono? c) Este polígono pode ser subdivido em quais polígonos?

Calcule as áreas destes polígonos.

d) Qual é a área total do polígono?

Tarefa 5.2: Construa no Geoplano o polígono.

Figura 11 - Polígono

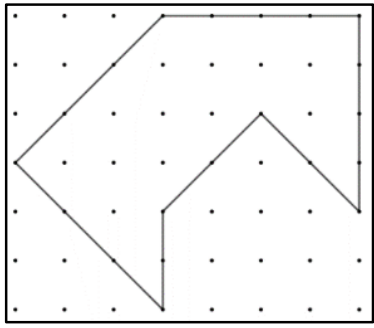

Fonte: Produção nossa.

a) Quantos lados têm este polígono?

b) Qual é o perímetro deste polígono?

c) Este polígono pode ser subdivido em quais polígonos?

Calcule as áreas destes polígonos?

d) Qual é a área total do polígono?

Quadro 4 - Atividade 6: tarefas 6.1 e 6.2

\begin{tabular}{|c|c|}
\hline $\begin{array}{l}\text { Atividade 6 - Estudo da área do Polígono com a } \\
\text { Fórmula de Pick } \\
\text { Objetivo: Conhecer e calcular a área de um polígono a partir } \\
\text { da Fórmula de Pick. } \\
\text { Nota: Consideremos como F o número de pontos do } \\
\text { Geoplano pertencentes à fronteira do polígono com os } \\
\text { vértices em pontos da rede; e com I o número de pontos da } \\
\text { rede interiores ao polígono. Seja A a área do polígono e } \\
\text { consideremos cada quadradinho como unidade de área. } \\
\text { Tarefa 6.1: Construa no Geoplano o polígono com pontos } \\
\text { I = } 0 \text {. }\end{array}$ & 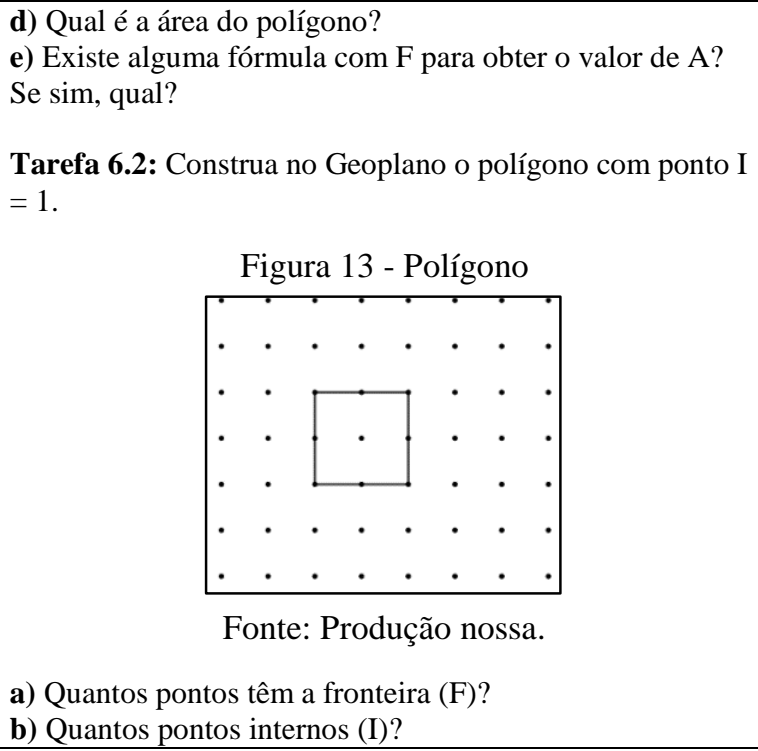 \\
\hline
\end{tabular}




\section{Figura 12 - Polígono}

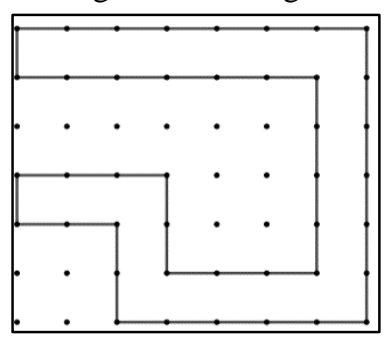

Fonte: Produção nossa.

a) Quantos pontos têm a fronteira $(\mathrm{F})$ ?

b) Quantos pontos internos (I)?

c) Qual é o perímetro do polígono?

Fonte: Produção nossa.

Quadro 5 - Atividade 6: tarefas 6.3 e 6.4

Tarefa 6.3: Construa no Geoplano o polígono com pontos $\mathrm{I}=2$
Figura 14 - Polígono

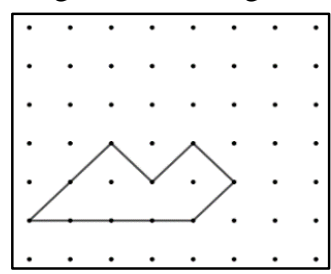

Fonte: Produção nossa. a) Quantos pontos têm na fronteira $(\mathrm{F})$ ?

b) Quantos pontos internos (I)?

c) Qual é o perímetro do polígono?

d) Qual é a área do polígono?

e) Existe alguma fórmula com $\mathrm{F}$ para obter o valor de A? Qual? c) Qual é o perímetro do polígono?

d) Qual é a área do polígono?

e) Existe alguma fórmula com $\mathrm{F}$ para obter o valor de A? Qual?

Fonte: Produção nossa.

Quadro 6 - Atividade 6: tarefa 6.5

Tarefa 6.5: Construa no Geoplano o triângulo retângulo e as relações pitagóricas.

Figura 16 - Triângulo retângulo

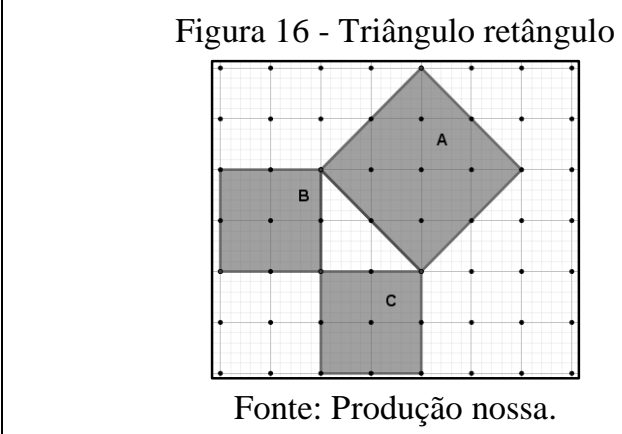

Fonte: Produção nossa.
Tarefa 6.4: Construa no Geoplano o polígono com Pontos I qualquer.

Nota: Portanto, a Fórmula de Pick, para qualquer I é:

$$
A=\frac{F}{2}+I-1
$$

Figura 15 - Polígono

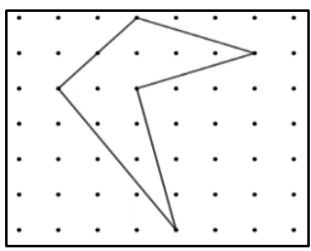

Fonte: Produção nossa.

a) Quantos pontos têm na fronteira (F)?

b) Quantos pontos internos (I)?

c) Existe alguma fórmula com $\mathrm{F}$ para obter o valor de $\mathrm{A}$ ? Escreva a fórmula que generaliza essa aplicação.

d) Qual é a área do polígono?
a) Quantos pontos têm na fronteira (F) do polígono B?
b) Quantos pontos internos (I) tem o polígono B?
c) Determine a área do polígono $\mathrm{B}$, utilizando a Fórmula de Pick.
d) Quantos pontos têm na fronteira (F) do polígono C?
e) Quantos pontos internos (I) têm o polígono C?
f) Determine a área do polígono C, utilizando a Fórmula de Pick. Que área você encontrou?
g) Quantos pontos têm na fronteira (F) do polígono A?
h) Quantos pontos internos (I) têm o polígono A?
i) Determine a área do polígono A, utilizando a Fórmula de Pick. Que valor você encontrou?
j) Se somarmos a área do polígono $\mathrm{B}$ e a área do polígono $\mathrm{C}$, obteremos a área do polígono $\mathrm{A}$ ?

Fonte: Produção nossa.

Quadro 7 - Atividade 7: tarefa 7.1 


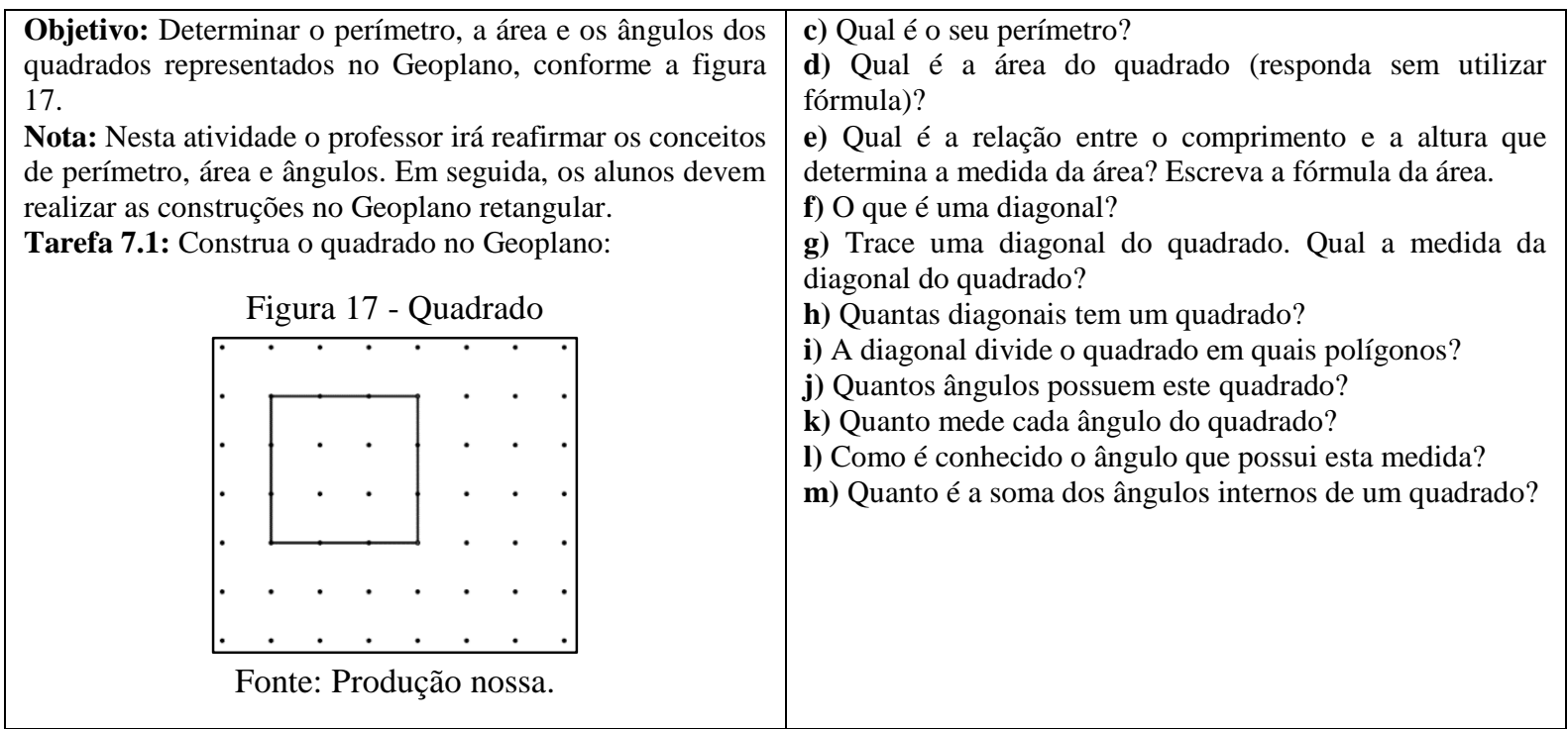

Fonte: Produção nossa.

Quadro 8 - Atividade 7: tarefa 7.2

\begin{tabular}{|c|l|}
\hline Tarefa 7.2: Construa o quadrado no Geoplano: & $\begin{array}{l}\text { a) Quais as características deste polígono? } \\
\text { b) Quanto mede cada lado (1) deste quadrado? } \\
\text { c) Qual o perímetro deste quadrado? } \\
\text { d) Qual é a área do quadrado (responda sem utilizar } \\
\text { fórmula)? } \\
\text { e) Verifique a área encontrada fazendo uso da fórmula }(A= \\
\text { l.l ou } A=l^{2} \text { ). } \\
\text { f) Quantos ângulos possuem este quadrado? } \\
\text { g) Quanto mede cada ângulo do quadrado? } \\
\text { h) Como é conhecido o ângulo que possui esta medida? } \\
\text { i) Quanto é a soma dos ângulos internos de um quadrado? }\end{array}$ \\
\hline Fonte: Produção nossa.
\end{tabular}

Fonte: Produção nossa.

Quadro 9 - Atividade 8: tarefa 8.1

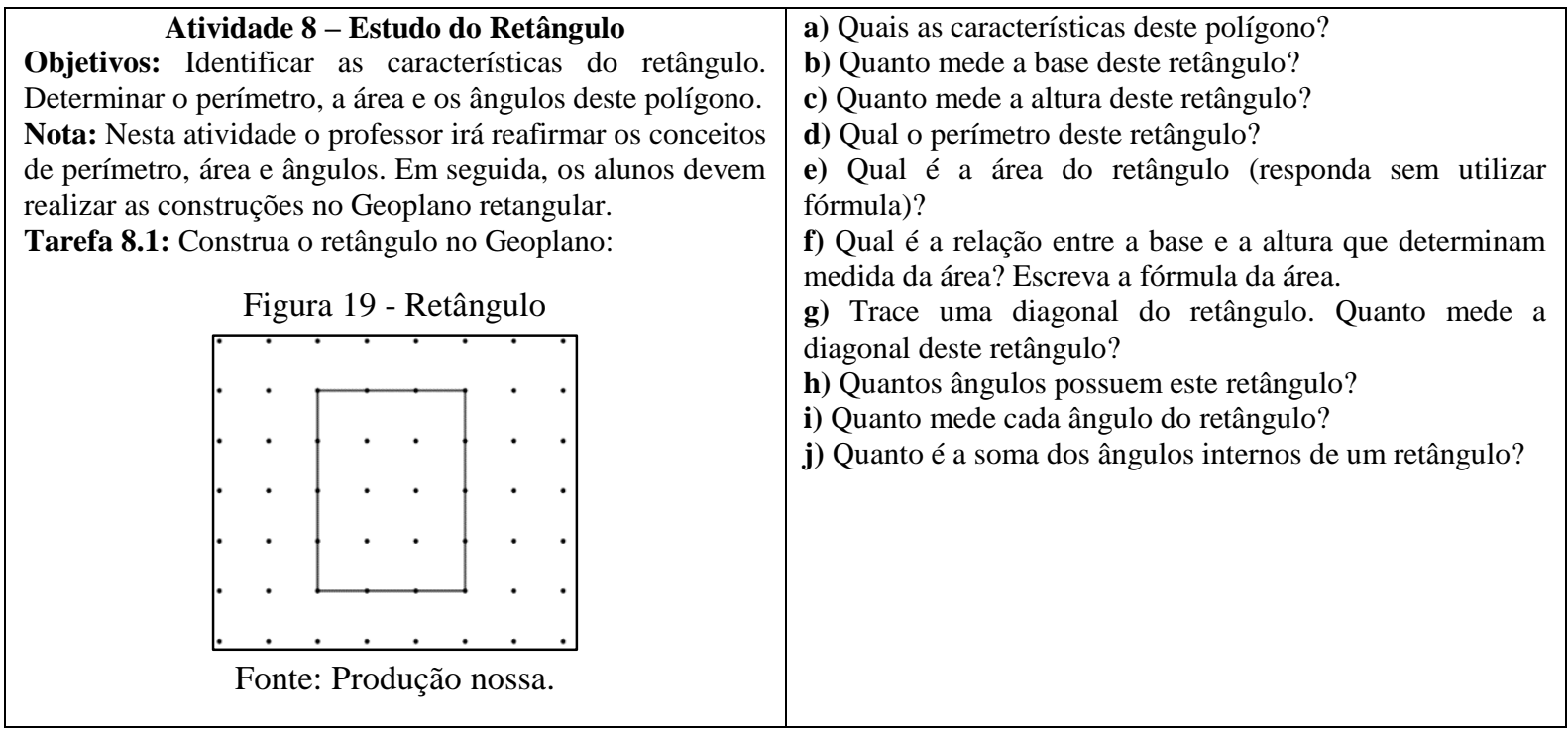

Fonte: Produção nossa. 
Quadro 10 - Atividade 8: tarefa 8.2

\begin{tabular}{|l|l|}
\hline Tarefa 8.2: Construa o retângulo no Geoplano: & $\begin{array}{l}\text { a) Quais as características deste polígono? } \\
\text { b) Quanto mede a base deste retângulo? } \\
\text { c) Quanto mede a altura deste retângulo? } \\
\text { d) Qual o perímetro deste retângulo? } \\
\text { e) Qual é a área do retângulo (responda sem utilizar } \\
\text { fórmula)? } \\
\text { f) Verifique a área encontrada fazendo uso da fórmula }(A= \\
b . h \text { ). } \\
\text { g) Trace uma diagonal do retângulo. Qual a sua medida? } \\
\text { h) Quantos ângulos possuem este retângulo? } \\
\text { i) Quanto mede cada ângulo do retângulo? } \\
\text { j) Como é conhecido o ângulo que possui esta medida? } \\
\text { k) Quanto é a soma dos ângulos internos de um retângulo? }\end{array}$ \\
\hline
\end{tabular}

Fonte: Produção nossa.

Quadro 11 - Atividade 9: tarefa 9.1

\section{Atividade 9 - Estudo do Paralelogramo}

Objetivos: Identificar as características do paralelogramo. Determinar o perímetro, a área e os ângulos deste polígono com auxílio do Geoplano.

Nota: Nesta atividade o professor irá reafirmar os conceitos de perímetro, área e ângulos. Em seguida, os alunos devem realizar as construções no Geoplano retangular.

Tarefa 9.1: No Geoplano construa o paralelogramo:

Figura 21 - Paralelogramo

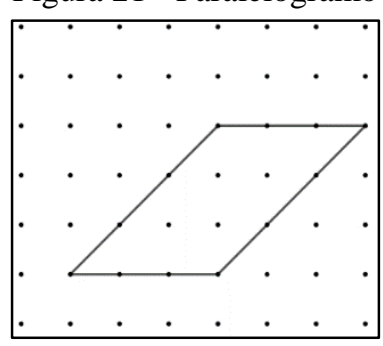

Fonte: Produção nossa. a) Quais as características deste polígono?

b) Quanto mede a base (b) deste paralelogramo?

c) Quanto mede a altura (h) deste paralelogramo?

d) Qual o perímetro deste paralelogramo?

e) Qual é a área do paralelogramo? (responda sem utilizar fórmula)

f) Qual é a relação entre a base e a altura que determinam a medida da área do paralelogramo? Escreva a fórmula da área.

g) Trace a diagonal maior do paralelogramo. Qual a sua medida?

h) Trace a diagonal menor do paralelogramo. Qual a sua medida?

i) Quantos ângulos possuem este paralelogramo?

j) Quanto mede cada ângulo do paralelogramo?

k) Quanto é a soma dos ângulos internos de um paralelogramo?

Fonte: Produção nossa.

Quadro 12 - Atividade 9: tarefa 9.2

\begin{tabular}{|c|c|}
\hline 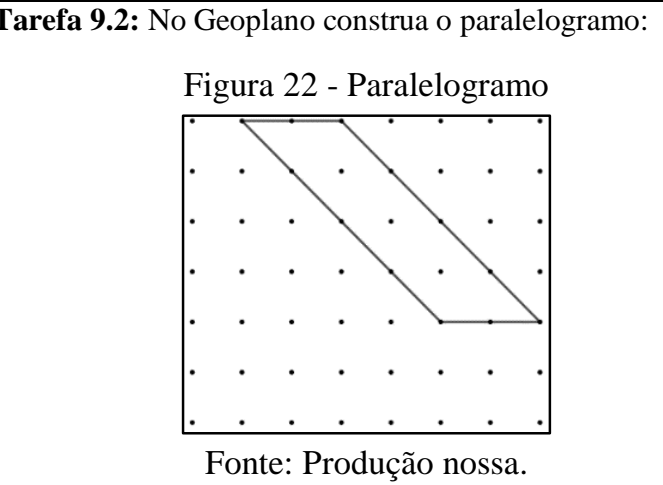 & $\begin{array}{l}\text { a) Quais as características deste polígono? } \\
\text { b) Quanto mede a base deste paralelogramo? } \\
\text { c) Quanto mede a altura deste paralelogramo? } \\
\text { d) Qual o perímetro deste paralelogramo? } \\
\text { e) Qual é a área do paralelogramo? (responda sem utilizar } \\
\text { fórmula) } \\
\text { f) Verifique a área encontrada fazendo uso da fórmula ( } A= \\
b . h \text { ). } \\
\text { g) Quantos ângulos possuem este paralelogramo? } \\
\text { h) Quanto mede cada ângulo do paralelogramo? } \\
\text { i) Quanto é a soma dos ângulos internos de um retângulo? }\end{array}$ \\
\hline
\end{tabular}

Fonte: Produção nossa.

Quadro 13 - Atividade 10: tarefa 10.1

Atividade 10 - Estudo dos Triângulos
Objetivos: Identificar as características do triângulo.
Determinar o perímetro, a área e os ângulos com uso do
Geoplano.

Atividade 10 - Estudo dos Triângulos

Determina a) Quais as características deste polígono?

b) Qual a classificação deste triângulo quanto aos seus lados?

c) Qual a classificação deste triângulo quanto aos seus 


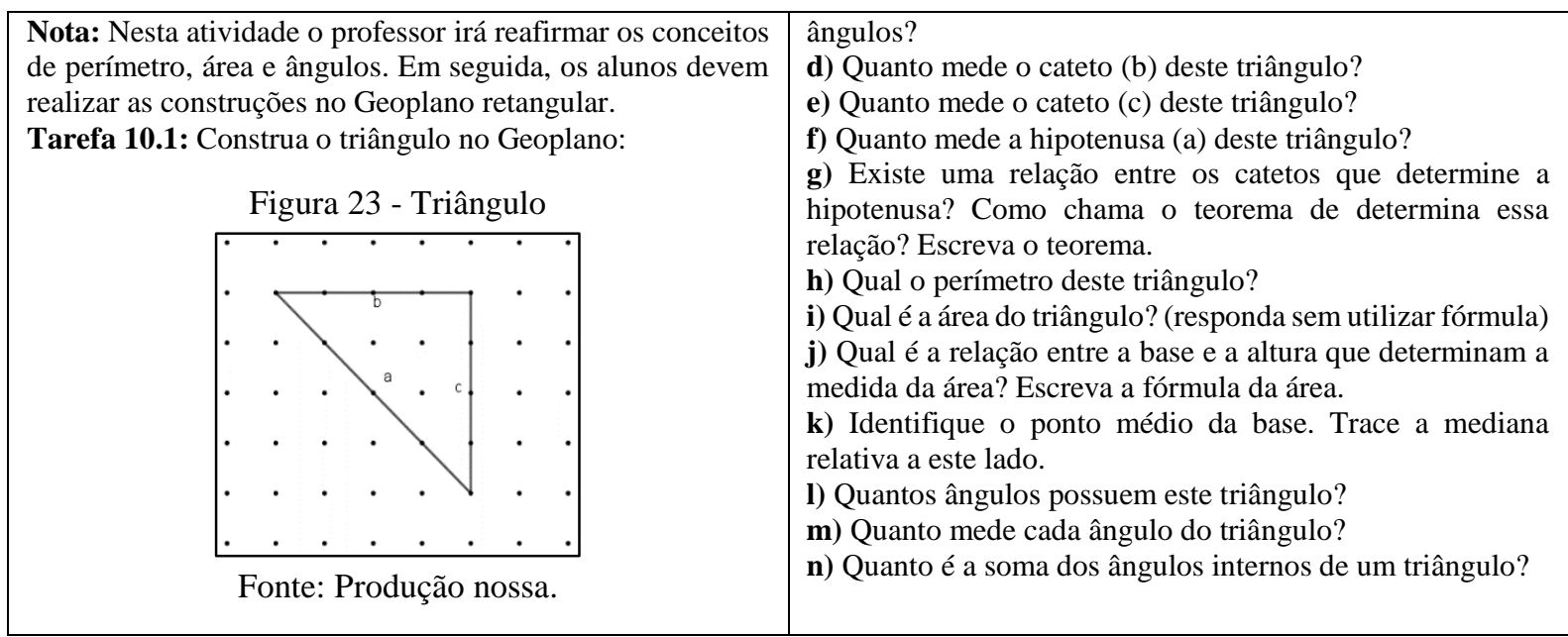

Fonte: Produção nossa.

Quadro 14 - Atividade 10: tarefa 10.2

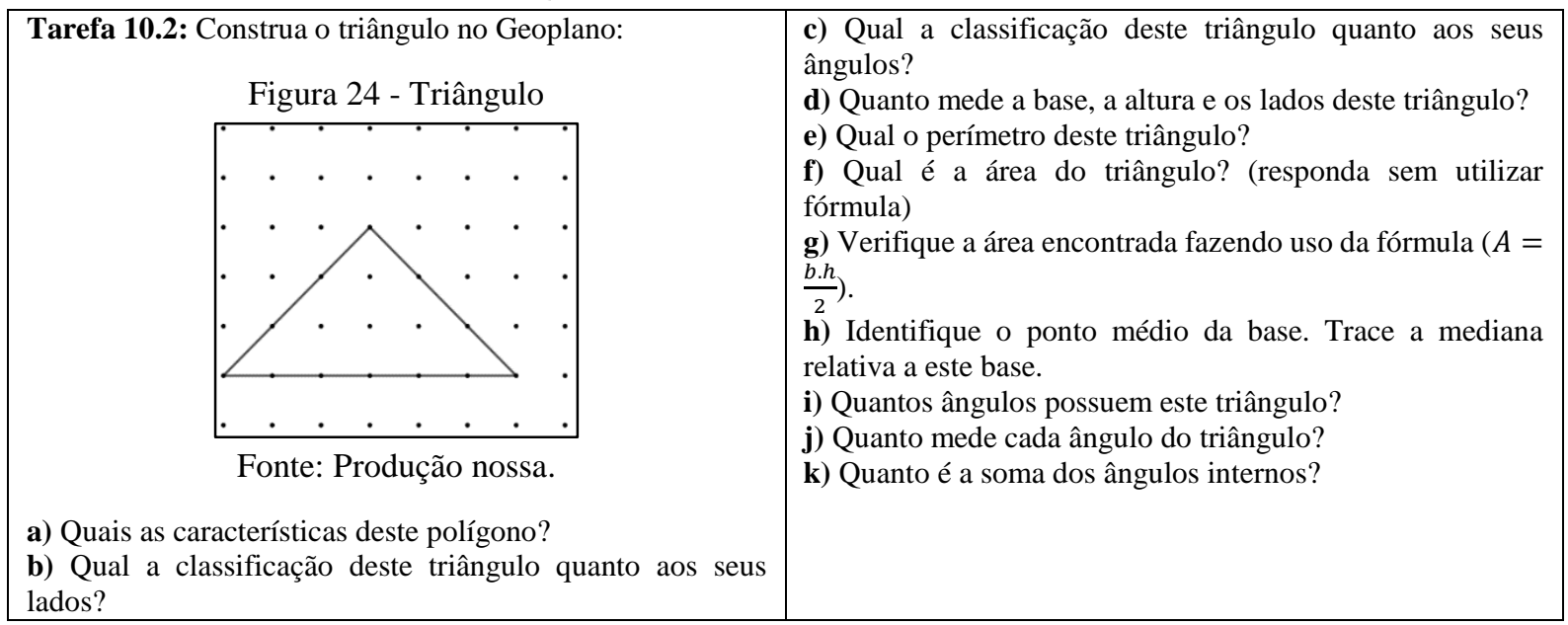

Fonte: Produção nossa.

Quadro 15 - Atividade 1: tarefa 10.3

\begin{tabular}{|c|c|}
\hline $\begin{array}{l}\text { Fonte: Produção nossa. } \\
\text { a) Quais as características deste polígono? }\end{array}$ & $\begin{array}{l}\text { b) Qual a classificação deste triângulo quanto aos seus } \\
\text { lados? } \\
\text { c) Qual a classificação deste triângulo quanto aos seus } \\
\text { ângulos? } \\
\text { d) Quanto mede a base deste triângulo? } \\
\text { e) Quanto mede os lados deste triângulo? } \\
\text { f) Qual o seu perímetro deste triângulo? } \\
\text { g) Qual é a área do triângulo? (responda sem utilizar } \\
\text { fórmula) } \\
\text { h) Verifique a área encontrada fazendo uso da fórmula ( } A= \\
\left.\frac{b . h}{2}\right) \text {. } \\
\text { i) Quantos ângulos possuem este triângulo? } \\
\text { j) Quanto mede cada ângulo do triângulo? } \\
\text { k) Quanto é a soma dos ângulos internos? }\end{array}$ \\
\hline
\end{tabular}

Fonte: Produção nossa.

Quadro 16 - Atividade 11

\begin{tabular}{|l|l|}
\hline \multicolumn{1}{|c|}{ Atividade 11 - Estudo do Losango } & a) Quais as características deste polígono? \\
Objetivo: Identificar as características do losango. & b) Trace a diagonal menor. Quanto mede a diagonal menor? \\
Determinar o perímetro, a área e os ângulos deste polígono & c) Trace a diagonal maior. Quanto mede a diagonal maior? \\
com auxílio do Geoplano. & d) Marque o ponto médio entre as diagonais? \\
Tarefa 11: Construa o losango no Geoplano: & e) O losango pode ser dividido em quais figuras? \\
\hline
\end{tabular}




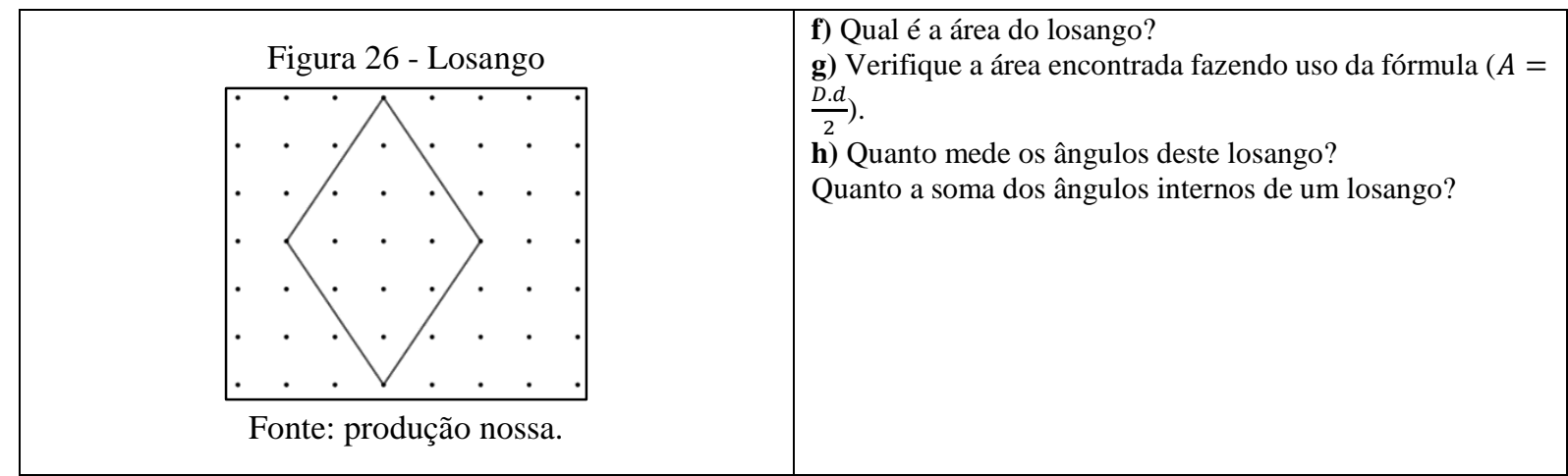

Fonte: Produção nossa.

Quadro 17 - Atividade 12: tarefa 12.1

\begin{tabular}{|l|l|}
\hline $\begin{array}{l}\text { Atividade 12 - Estudo do Trapézio } \\
\text { Objetivo: Identificar as características do trapézio. } \\
\text { Determinar o perímetro, a área e os ângulos deste polígono. } \\
\begin{array}{l}\text { Nota: Nesta atividade o professor irá reafirmar os conceitos } \\
\text { de perímetro, área e ângulos. Em seguida, os alunos devem } \\
\text { realizar as construções no Geoplano retangular. } \\
\text { Tarefa 12.1: Construa o trapézio no Geoplano: }\end{array}\end{array}$ & $\begin{array}{l}\text { a) Quais as características deste polígono? } \\
\text { b) Quanto mede a base maior (B) deste trapézio? } \\
\text { c) Quanto mede a base menor (b) deste trapézio? } \\
\text { d) Quanto mede a altura (h) deste trapézio? } \\
\text { e) Quanto mede os lados do trapézio? } \\
\text { f) Qual o perímetro deste trapézio? } \\
\text { g) Qual é a área do trapézio (responda sem utilizar fórmula)? } \\
\text { h) Qual é a relação entre a base maior, a base menor e altura, } \\
\text { que determinam a medida da área? Escreva a fórmula da área } \\
\text { do trapézio. } \\
\text { i) Quantos ângulos possuem o trapézio? } \\
\text { j) Quanto mede cada ângulo do trapézio? } \\
\text { k) Quanto a soma dos ângulos internos de um trapézio } \\
\text { retângulo? }\end{array}$ \\
$\qquad \begin{array}{ll}\text { Figura 27 - Trapézio retângulo } \\
\text { Fonte: Produção nossa. }\end{array}$ & \\
\hline
\end{tabular}

Fonte: Produção nossa.

Quadro 18 - Atividade 12: tarefa 12.3

\begin{tabular}{|c|c|}
\hline 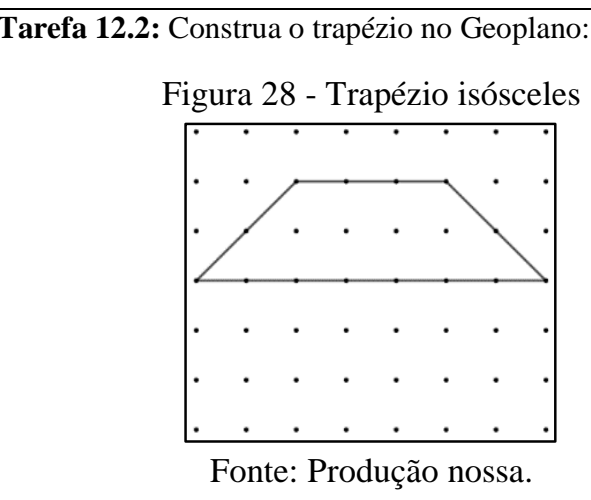 & $\begin{array}{l}\text { a) Quais as características deste polígono? } \\
\text { b) Quanto mede a base maior (B) deste trapézio? } \\
\text { c) Quanto mede a base menor (b) deste trapézio? } \\
\text { d) Quanto mede a sua altura? } \\
\text { e) Quanto mede os lados do trapézio? } \\
\text { f) Qual o perímetro deste trapézio? } \\
\text { g) Qual é a área do trapézio (responda sem utilizar fórmula)? } \\
\text { h) Verifique a área encontrada fazendo uso da fórmula }(A= \\
\left.\frac{(B+b) h}{2}\right) \text {. } \\
\text { i) Quantos ângulos possuem este trapézio? } \\
\text { j) Quanto mede cada ângulo do trapézio? } \\
\text { k) Quanto é a soma dos ângulos internos de um trapézio } \\
\text { retângulo? }\end{array}$ \\
\hline
\end{tabular}

Fonte: produção nossa.

Não contentes apenas com a proposta, que por natureza pode ser considerada inovadora, desenvolvemos a SD construída com os estudantes da Educação Básica e, posteriormente, descrevemos esse desenvolvimento e interpretamos algumas falas dos estudantes sobre esse processo. Sobre isso, explicaremos nos tópicos. 


\section{Desenvolvimento da SequênCia Didática}

Neste tópico apresentamos o lócus da pesquisa, os procedimentos metodológicos e o desenvolvimento da Sequência Didática no Colégio Estadual Professora Joana Batista Cordeiro (JBC), no município de Arraias (TO), em uma turma de $1^{\mathrm{a}}$ série do Ensino Médio, composta por 24 estudantes.

O Colégio JBC, no período da realização desta investigação, possuía 4 (quatro) turmas de $1^{\mathrm{a}}$ série e 4 (quatro) turmas de $2^{\mathrm{a}}$ série do Ensino Médio do Programa de Fomento às escolas de Ensino Médio em Tempo Integral. Este programa foi implantado pelo Governo do Estado do Tocantins através da Secretaria de Estado da Educação, Cultura e Esporte (SEDUC) com a perspectiva de promover uma formação educacional de qualidade, visando a melhoria do Ensino Médio ofertado no Tocantins, assumindo um novo modelo pedagógico e de Gestão, idealizado pelo Instituto de Corresponsabilidade pela Educação (ICE). Esse modelo foi inicialmente implantado no Estado do Pernambuco e está sendo implantado no Tocantins e em outros Estados da federação.

Esse modelo de escola é organizado por 4 (quatro) áreas de conhecimento: Linguagens, Ciências da Natureza, Matemática e Ciências Humanas. Cada área possui as suas respectivas disciplinas e quantidades de aulas, a saber: Linguagens - 6 (seis) aulas de Língua Portuguesa, 1 (uma) aula de Arte, 2 (duas) aulas de Educação Física, 2 (duas) aulas de Língua Estrangeira Moderna - Inglês, 1 (uma) aula de Redação; Ciências da Natureza - 3 (três) aulas de Química, 3 (três) aulas de Biologia, 3 (três) aulas de Física, 1 (uma) aula de Prática de Química, 1 (uma) aula de Prática de Biologia, 1 (uma) aula de Prática de Física; Matemática - 6 (seis) aulas de Matemática, 1 (uma) aula de Prática de Matemática; Ciências Humanas - 2 (duas) aulas de Geografia, 2 (duas) aulas de História, 1 (uma) aula de Filosofia, 1 (uma) aula de Sociologia. Estas áreas e disciplinas compõem o núcleo comum. Além destas disciplinas o currículo escolar é composto pela parte diversificada que compreende às disciplinas e quantidades de aulas, a saber: 2 (duas) aulas de Estudo Orientado, 2 (duas) de Eletivas e 2 (duas) de Avaliação Semanal. Assim, totalizando 45 (quarenta e cinco) aulas, semanalmente, por turma.

A Sequência Didática para o ensino de figuras planas com o auxílio do Geoplano foi desenvolvida em uma turma de $1^{\text {a }}$ série do Ensino Médio, conhecida por seu código estadual como 13.03. Essa turma possuía 24 (vinte e quatro) alunos. Entendemos pertinente destacar que dos 24 alunos, 23 (vinte e três) moravam na cidade e um no campo e que este aluno possuía transporte escolar e percorria cerca de $95 \mathrm{~km}$ de sua casa até a escola, gastando em média duas horas de viagem para ir e mais duas horas em média para voltar da escola até sua casa. 
Para o desenvolvimento da Sequência Didática, realizamos uma parceria com o Laboratório de Ensino de Matemática (LEM) da Universidade Federal do Tocantins (UFT) Câmpus de Arraias. Antes da realização da Sequência Didática foi necessário um primeiro contato com a professora de Matemática da turma, que por meio de uma conversa rápida explicamos sobre a Sequência Didática e seus objetivos. Após o consentimento da professora, procuramos a Coordenação Pedagógica e a Direção da escola e apresentamos sobre este trabalho de pesquisa e seus objetivos. A Coordenação Pedagógica e a Direção consentiram e acharam interessante o desenvolvimento de uma atividade prática por uma professora Licenciada em Matemática, mas que nesta escola não atuava na área. Ressaltaram que esse modelo de escola preconiza o trabalho colaborativo entre professores em uma mesma disciplina de forma a contribuir com conhecimentos e metodologias diferentes que auxiliarão na construção do conhecimento do aluno.

A Sequência Didática que construímos sobre figuras planas com o auxílio do Geoplano é composta por 12 (doze) atividades, conforme apresentamos anteriormente. Para viabilizar o seu desenvolvimento, a turma foi organizada em 8 (oito) grupos de 3 (três) estudantes em cada, que nos referimos como: G1, G2, G3, G4, G5, G6, G7 e G8. Para o desenvolvimento da Sequência Didática foram necessárias 6 (seis) aulas de 50 (cinquenta) minutos, sendo a pesquisa desenvolvida em duas aulas por dia. No último dia, os 15 (quinze) minutos finais foram destinados aos alunos responderem um questionário aberto contendo 6 (seis) questões.

Organizamos a sala de aula e colocamos sobre a mesa os Geoplanos, os elásticos coloridos e a Sequência Didática impressa. Em seguida, conversamos com os alunos sobre a pesquisa e a importância da participação deles na realização dessas atividades. Posteriormente, apresentamos o Material Didático Geoplano e as atividades e deixamos os estudantes explorarem livremente o MD, onde começaram a construir figuras, indagar, interagir e conjecturar entre os participantes dos grupos. Com essa percepção, concordamos com Lorenzato (2006, p. 26) quando afirma que "o professor deve dar um tempo para que realizem uma livre exploração". É um momento muito importante para despertar o interesse, a motivação e a curiosidade dos estudantes.

As atividades foram desenvolvidas pelos grupos, onde trocaram informações, indagaram, conjecturaram e obtiveram soluções. Inicialmente, apresentamos os objetivos das atividades, pedimos aos alunos que construíssem as figuras planas e eles respondiam as questões investigativas em grupos. Somente avançávamos para a próxima atividade depois que 
todos os grupos tivessem respondido e explorado todas as questões investigativas de cada atividade.
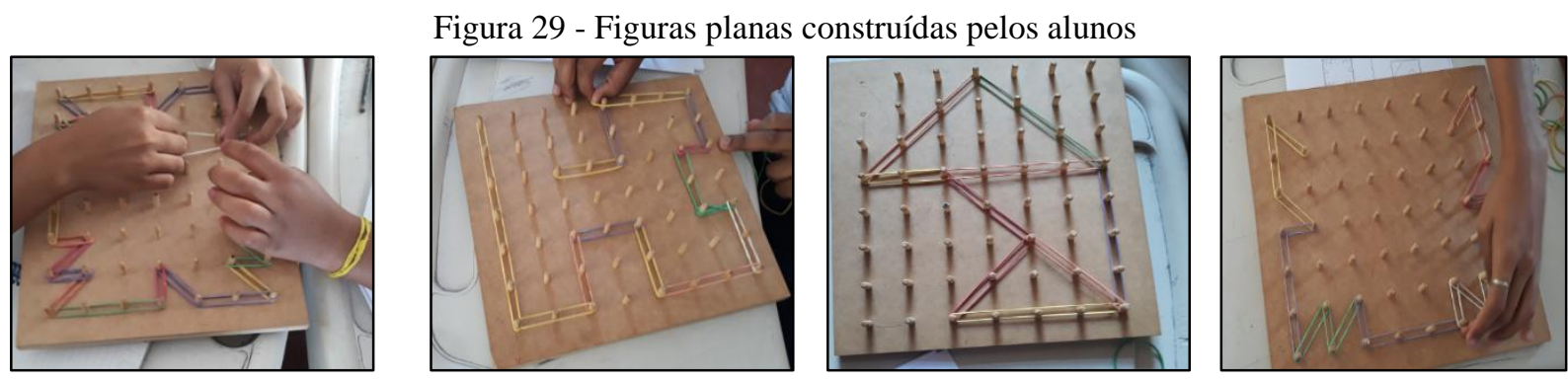

Fonte: Produção nossa

Acompanhamos todas as atividades e esclarecemos dúvidas individuais e coletivas, dando aos alunos mecanismos para entender a questão e construírem as suas respostas. Como nosso espaço é pouco para apresentar essa interação, detalhadamente, e as atividades desenvolvidas pelos grupos, optamos em não apresentá-las aqui e focamos nas análises do desenvolvimento da Sequência Didática, exclusivamente, por meio das respostas que os estudantes deram ao questionário que desenvolvemos com eles no final da Sequência Didática.

\section{ANÁLISE do QUESTIONÁRIO RESPONDIDO PELOS ALUNOS}

Com o intuito de compreendermos o que os alunos pensaram a respeito do material didático Geoplano e da Sequência Didática, desenvolvemos um questionário com perguntas abertas. Dele extraímos relatos dos grupos que consideramos fundamentais para nossa análise e organizamos as perguntas e respostas em quadros. O questionário possui 6 (seis) questões sobre o Geoplano. O mesmo foi distribuído aos grupos, onde leram e no coletivo formularam as respostas das questões.

A primeira indagação do questionário foi: "Por que vocês acham que o material didático apresentado possui esse nome?". Segue abaixo as respostas dos grupos.

Quadro 19 - Respostas dos grupos

\footnotetext{
G1: "Porque a partir desse material didático conseguimos confeccionar figuras geométricas planas".

G2: "Porque ele é plano e utilizamos para construirmos figuras planas".

G3: "Porque se refere a geometria e figuras planas".

G4: "Porque com esse material é possível construirmos e estudarmos as figuras planas".

G5: "Porque auxilia no estudo das figuras geométricas planas".

G6: "Porque com ele foi possível construir e estudar as características das figuras geométricas planas".

G7: "Porque é plano, construímos e estudamos as figuras planas".

G8: "Porque é uma tábua com pinos, parecido com a malha quadriculada, onde construímos figuras planas".
}

Fonte: Produção nossa.

Observamos nos relatos dos grupos que eles reconhecem a finalidade do material didático em se tratando do estudo sobre as figuras geométricas planas, associando o material 
didático Geoplano com as figuras planas construída no mesmo. Os relatos dos alunos nos remetem ao modo de ver e conceber o material didático Geoplano de Knijnik, Basso e Klusener (1996), Machado (2004), Menezes (2008) e Tiggermann et al (2013), onde ressaltam a importância do material didático no ensino de figuras planas. Machado (2004) destaca que "o Geoplano é um meio, uma ajuda didática, que oferece um apoio à representação mental e uma etapa para o caminho da abstração, proporcionando uma experiência geométrica e algébrica aos estudantes".

$\mathrm{Na}$ segunda questão indagamos sobre as dificuldades ao utilizar o Geoplano: "Você sentiu alguma dificuldade no manuseio do Geoplano? Justifique". Os grupos responderam:

Quadro 20 - Respostas dos grupos

G1: "Não, com o geoplano é fácil construir as figuras".

G2: "Não, porque estava fácil de construir e compreender".

G3: "Não, porque é um material didático simples e de fácil manuseio, necessitando apenas de elásticos coloridos para a construção das figuras geométricas planas".

G4: "Não, no geoplano e fácil construir as figuras, necessitando apenas de elásticos".

G5: "Sim, porque para o desenvolvimento e compreensão de algumas atividades necessitamos do auxílio da professora".

G6: "Não, foi fácil construir e estudar as figuras planas".

G7: "Não, o geoplano é um recurso simples e facilita o estudo das figuras planas".

G8: "Não, o geoplano é fácil de manusear".

Fonte: Produção nossa.

Podemos observar nas respostas que 7 (sete) grupos não tiveram dificuldades em manusear o material didático Geoplano, em desenvolver as atividades e em compreender os conceitos matemáticos objetivados em cada uma das tarefas propostas. Apenas um grupo (G5) ressaltou a dificuldade em desenvolver e compreender algumas atividades com o uso do Geoplano, necessitando da orientação da professora pesquisadora.

O uso de materiais didáticos nas aulas de Matemática é fundamental para o desenvolvimento do raciocínio lógico, observações, constatações, descobertas, levantamento de hipóteses, conjecturas e construção do conhecimento matemático. Os relatos dos alunos vão ao encontro das ideais de Knijnik, Basso e Klusener (1996), ao ressaltarem que o desenvolvimento das atividades do Geoplano é relativamente simples, necessitando apenas do Geoplano e elásticos coloridos. Concordamos com Mendes (2009, p. 26) quando afirma que "a aprendizagem é um processo progressivo que não se esgota na manipulação de modelos físicos, mas nas relações manipulativo-simbólicas e abstrativas estabelecidas em cada atividade".

Podemos observar nos relatos dos grupos o uso dos materiais didáticos nas aulas de Matemática a partir das respostas ao seguinte questionamento: “Algum professor já utilizou os Materiais Didáticos (MDs) nas aulas de Matemática? Se sim, quais?” 
Quadro 21 - Respostas dos grupos

G1: "Sim, usamos os Blocos Lógicos, Material Dourado e algumas vezes construímos figuras geométricas com dobradura".

G2: "Sim, Tangram e Material Dourado".

G3: "Sim, Xadrez, Dama e Material Dourado".

G4: "Sim, temos uma aula prática de Matemática, onde a professora desenvolve atividades práticas no laboratório de Matemática da escola, onde já usamos o Material Dourado e Tangram”.

G5: "Sim, nas aulas práticas de Matemática já usamos o Material Dourado, Dominó e Xadrez".

G6: "Sim, a professora já utilizou Tangram e Material Dourado e às vezes construímos algumas materiais".

G7: "Sim, a professora já usou o Material Dourado e fizemos algumas dobraduras".

G8: "Sim, vamos para o laboratório de Matemática nas aulas práticas ou mesmo em sala e usamos o Material Dourado, Xadrez, Dominó de Fração e Blocos Lógicos".

Fonte: Produção nossa.

Percebemos, nas respostas apresentadas pelos alunos, que esse modelo de escola garante ao aluno, em sua matriz curricular, uma aula prática de Matemática, semanalmente, onde a professora regente desenvolve atividades fazendo uso do laboratório de Matemática ou mesmo em sala de aula, de materiais didáticos voltados para o estudo das figuras geométricas e do desenvolvimento do pensamento lógico e investigativo. Assim, as aulas práticas de Matemática contribuem para o entendimento das aulas teóricas. Esse confronto entre teoria e prática é essencial na construção do saber matemático. Observamos, nos relatos dos alunos, que há a utilização de materiais didáticos nas aulas, principalmente nas atividades prática, conforme preconiza Lorenzato (2006), ao destacar que os materiais didáticos devem ser usados nas aulas de Matemática e o laboratório é o espaço fundamental para isso. Concordamos com esse autor ao afirmar que:

Para o aluno, mais importante que conhecer as verdades matemáticas, é obter a alegria da descoberta, a percepção da sua competência, a melhoria da sua autoimagem, a certeza que vale a pena procurar soluções e fazer constatações, a satisfação do sucesso e compreender a Matemática (LORENZATO, 2006, p. 25).

Continuamos a nossa investigação, onde indagamos aos alunos sobre: "Você acha que os Materiais Didáticos (MDs) contribuem na aprendizagem da Matemática? De que forma?”

Quadro 22 - Respostas dos grupos

G1: "Sim, esses tipos de materiais didáticos facilitam o aperfeiçoamento das atividades realizadas nas aulas de
Matemática".
G2: "Sim, os materiais didáticos facilitam e podemos compreender o conteúdo de Matemática".
G3: "Sim, os materiais didáticos reforçam o entendimento dos conteúdos, a partir de imagens e manuseio do
material".
G4: "Sim, com os materiais didáticos aprendemos melhor o conteúdo e aprender com a prática é legal".
G5: "Sim, pois ajuda a compreender melhor o conteúdo".
G6: "Sim, o Geoplano ajudou no entendimento das figuras geométricas que estamos estudando".
G7: "Sim, eles ajudam na compreensão da teoria".
G8: "Sim, eles tornam a Matemática mais fácil".

Fonte: Produção nossa. 
Podemos perceber nos relatos dos grupos o reconhecimento da importância do uso de materiais didáticos para as aulas de Matemática como um recurso facilitador. Os relatos dos alunos mostram o que Lorenzato (2006) preconiza em relação ao uso de materiais didáticos, que é fundamental que se tenha tarefas investigativas simples que vão avançando para conceitos mais abstratos que podem ser explorados pelo material didático. Concordamos também com Bittar e Freitas (2005, p. 29) ao afirmarem que "o material didático deve ser visto como um instrumento facilitador da aprendizagem, porém, não se trata de um instrumento mágico com o qual tudo poderá ser entendido e assimilado pelo aluno".

Ao fazermos a pergunta: “O Material Didático Geoplano contribuiu na aprendizagem de figuras planas? Justifique.”, obtivemos as seguintes respostas:

Quadro 23 - Respostas dos grupos

G1: "Sim, o Geoplano nos ajuda a calcular áreas das figuras planas sem a utilização de fórmulas, com ele estabelecemos e compreendemos as fórmulas e cálculos das áreas de figuras planas".

G2: "Sim, o material didático Geoplano contribuiu para aprimorarmos os nossos conhecimentos de figuras planas".

G3: "Sim, ele reforçou o conteúdo de figuras planas".

G4: "Sim, a construção das figuras planas com elásticos é fácil e a partir dela compreendemos os conceitos de perímetro e área dos polígonos".

G5: "Sim, pois compreendemos melhor as figuras planas".

G6: "Sim, pois aprendemos de uma forma mais extrovertida e fácil".

G7: "Sim, o Geoplano nos ajudou a compreendermos os conceitos de figuras planas".

G8: "Sim, o Geoplano possibilitou a compreender mais as figuras planas".

Fonte: Produção nossa.

Evidenciamos nos relatos dos grupos as contribuições do material didático Geoplano no ensino de figuras planas, onde o mesmo possibilitou, ao construir as figuras, aprimorar os conhecimentos, compreender as figuras planas e aprender de forma lúdica. Concordamos com Knijnik, Basso e Klusener (1996, p. 8) ao afirmarem sobre Geoplano que "sua utilização se dê como uma ferramenta auxiliar no trabalho de Matemática, a partir de situações que de fato sejam relevantes no e para o universo dos/as alunos/as. As atividades podem ser trabalhadas em pequenos grupos ou individualmente".

Para finalizarmos o nosso questionário, perguntamos aos grupos: "De que forma o Material Didático Geoplano contribuiu na aprendizagem de figuras planas?"

Quadro 24 - Respostas dos grupos

G1: "O material didático Geoplano nos possibilitou manusear, construir as figuras planas com elásticos e identificar suas características".

G2: "No Geoplano construímos as figuras planas e analisamos as suas características".

G3: "O material didático Geoplano reforçou os conteúdos de figuras planas".

G4: "O material didático Geoplano contribuiu para aprimorarmos o nosso conhecimento de figuras planas".

G5: "Com a construção de figuras planas no Geoplano foi possível compreendermos melhor o conteúdo de Matemática de figuras planas". 
G6: "O Geoplano nos ajudou a compreendermos o conteúdo de figuras planas, através das construções e estudo das características das figuras".

G7: "O Geoplano contribui na aprendizagem de figuras planas, com ele foi possível construímos de forma fácil as figuras, analisarmos as características das figuras através de questões investigatórias e compreendermos os conceitos matemáticos".

G8: "Com o material didático Geoplano, construímos figuras planas, respondemos as questões da Sequência Didática no coletivo, onde houve uma troca de conhecimentos no grupo.

Fonte: Produção nossa.

Nas falas dos alunos ficou evidente que conseguiram aprender os conceitos ao tocar, sentir, manipular, movimentar e conjecturar, conforme aponta Lorenzato (2006) e Mendes (2009). Esses elementos são inerentes à utilização do uso do MD Geoplano e possibilitam reflexões intencionais em se tratando dos conceitos e conteúdos matemáticos em questão.

Percebemos que o desenvolvimento das atividades para ensinar figuras planas a partir do uso do MD Geoplano contribuiu de forma significativa para os estudantes possam construir, aprimorar, investigar e conjecturar os conceitos, elementos e objetos matemáticos. A Sequência Didática possibilitou a construção e o aprimoramento do conhecimento de figuras planas, partindo de conceitos primitivos como ponto e segmento de reta até as aplicações do Teorema de Pitágoras e subdivisão de polígonos de áreas definidas.

Durante o desenvolvimento da Sequência Didática com o material didático Geoplano, observamos que sua utilização contribui para o processo de ensino e aprendizagem, promovendo: aulas atrativas e interessantes para os estudantes, a motivação, o caráter investigativo, o raciocínio lógico investigativo, a coletividade, o respeito às diferentes ideias dos estudantes, o levantamento de hipóteses e conjecturas, a construção do conhecimento matemático por parte dos estudantes.

\section{Algumas CONSIDERAÇÕeS}

Neste trabalho desenvolvemos uma Sequência Didática com 12 (doze) atividades envolvendo a construção e questionamentos investigativos sobre o material didático Geoplano no ensino das figuras planas. Percebemos, nos relatos dos alunos, a importância e reconhecimento dos materiais didáticos nas aulas de Matemática, pois o seu uso pode tornar as aulas mais atrativas e interessantes, possui um caráter motivador, os alunos apreciam e gostam das atividades lúdicas. Além disso, a utilização do material didático Geoplano possibilita o trabalho em grupo, a troca de conhecimento no coletivo, o respeito a opinião dos colegas e a construção de conhecimento matemático.

Os materiais didáticos facilitam o entendimento dos conteúdos matemáticos. Para isso, é necessário que o professor elabore uma Sequência Didática investigativa sobre o material em 
estudo, pois o material didático por si só não garante o ensino de qualidade e nem a aprendizagem. Mas, quando o professor consegue elaborar atividades bem sequenciadas, estruturadas e organizadas em torno do conteúdo a ser ensinado, utilizando o MD possível e necessário, visando a investigação por parte do estudante, a interação em grupo e a participação do professor como mediador, torna-se possível, viável e um elemento essencial para a melhoria do processo de ensino e aprendizagem de Matemática. Portanto, acreditamos e defendemos que esse tipo de prática, que toma como ferramenta a utilização de SD, pode contribuir para o desenvolvimento coerente, intencional, planejado e didático de situações de ensino e aprendizagem favoráveis à aprendizagem dos estudantes.

O Geoplano é um material didático muito rico no estudo da geometria plana. A partir do seu uso é possível explorar diversos conteúdos de forma dinâmica e interessante para os alunos. Com o desenvolvimento da Sequência Didática foi possível perceber os alunos construindo hipóteses, conjecturando, trocando ideias e, ao final, uma voz de "Ah, agora entendi!". O Geoplano retangular possui limitações, mas é uma alternativa que estimula o interesse dos alunos e enriquece o ambiente de aprendizagem.

Neste artigo apresentamos uma Sequência Didática para o ensino de figuras planas, desenvolvida com discentes da $1^{\text {a }}$ Série do Ensino Médio. Apresentamos, também, como uma proposta metodológica que pode ser adaptada por professores que tenham interesse em utilizar o Geoplano no estudo de figuras planas. É importante que outras sequências didáticas sejam construídas, fazendo uso do Geoplano circular e isométrico, como forma de estudar outras figuras planas que não puderam ser exploradas com o Geoplano retangular, a fim de que possa ampliar o conhecimento dos alunos sobre esse e outros conteúdos matemáticos.

\section{REFERÊNCIAS}

BITTAR, Marilena; FREITAS, José Luiz Magalhães de. Fundamentos e metodologia de Matemática para os ciclos iniciais do ensino fundamental. 2. ed. Campo Grande, MS: Ed. UFMS, 2005.

COSTA, Dailson Evangelista; PEREIRA, Marcos José; MAFRA, José Ricardo e Souza. Geoplano no ensino de Matemática: Alguns aspectos e perspectivas da sua utilização na sala de aula. Amazônia: Revista de Educação em Ciências e Matemáticas, [S.1.], v. 7, p. 43-52, jun. 2011. ISSN 2317-5125. Disponível em:

https://periodicos.ufpa.br/index.php/revistaamazonia/article/view/1695. Acesso em: 27 mar. 2019.

COSTA, Dailson. Evangelista. O processo de construção de Sequência Didática como (pro)motor da educação Matemática na formação de professores. 2013. $192 \mathrm{f}$.

Dissertação (Mestrado) - Universidade Federal do Pará, Instituto de Educação Matemática e 
Científica, Belém, 2013. Programa de Pós-Graduação em Educação em Ciências e Matemáticas.

D'AMBROSIO, Ubiratan. Educação Matemática: da teoria à prática. 17 ed. Campinas, SP: Papirus, 2009. (Coleção perspectivas em Educação Matemática).

D'AMBROSIO, Ubiratan. Matemática, ensino e educação: uma proposta global. In: Sbem temas \& debates. Matemática, Ensino e educação: concepções fundamentais. Ano IV, n. 3. Rio Claro, SP, 1991.

DIAS, Marcelo. Tendências em Educação Matemática: Percursos Curriculares Brasileiros e Paraguaios. Curitiba-PR: Editora Appris, 2016.

FIORENTINI, Dario; LORENZATO, Sérgio. Investigação em educação Matemática: percursos teóricos e metodológicos. 3. ed. rev. Campinas, SP: Autores Associados, 2012.

FIORENTINI, Dário; MIORIM, Maria Ângela. Uma reflexão sobre o uso de materiais concretos e jogos no ensino da Matemática. Boletim da SBEM-SP, julho-agosto de 1990. p. 7.

FLEMMING, Diva Marília; LUZ, Elisa Flemming; MELLO, Ana Claúdia Collaço de. Tendências em educação Matemática.2 ed. Palhoça, SC :Unisul Virtual, 2005.

KNIJNIK, Gelsa; BASSO, Marcus Vinicius; KLÜSENER, Renita. Aprendendo e ensinando Matemática com o Geoplano. 2 ed. Ijuí, RS: Ed. Unijuí, 1996. (Biblioteca do professor. Coleção Programa do Livro na Escola).

LORENZATO, Sérgio. (org.). O laboratório de ensino de Matemática na formação de professores. Campinas, SP: Autores Associados, 2006. (Coleção Formação de Professores).

LÜDKE, Menga; ANDRÉ, Marli Eliza Dalmazo Afonso. Pesquisa em educação: abordagens qualitativas. São Paulo: EPU, 1986.

MACHADO, Rosa Maria. Minicurso explorando o geoplano. In: II Bienal da Sociedade Brasileira de Matemática, 2004. Disponível em: http://www.bienasbm.ufba.br/M11.pdf. Acesso em: 01 de novembro de 2018.

MATOS, José Manoel; SERRAZINA, Maria de Lurdes. Didática da Matemática. Lisboa: 1996.

MENDES, Iran Abreu. Matemática e investigação em sala de aula: tecendo redes cognitivas na aprendizagem. 2 ed. São Paulo: Editora Livraria da Física, 2009.

MENEZES, Josinalva Estácio. (org.). Conhecimento, interdisciplinaridade e atividades de ensino com jogos matemáticos: uma proposta metodológica. Recife: UFRPE, 2008. (Série Contexto Matemático)

NACARATO, Adair Mendes. Eu trabalho primeiro no concreto. Revista de Educação Matemática - Ano 9, N 9--10 (2004-2005) p.1-6. 
RÊGO, Rogéria Gaudencio do; RÊGO, Rômulo Marinho do; VIEIRA, Kleber Mendes; Uma Introdução. In: RÊGO, Rogéria Gaudencio do; RÊGO, Rômulo Marinho do; VIEIRA, Kleber Mendes. Laboratório de ensino de geometria. Campinas, SP: Autores Associados, 2012. (Coleção formação de professores).

RODRIGUES, Fredy Coelho; GAZIRE, Eliane Scheid. Laboratório de Educação Matemática na Formação de Professores. Curitiba, PR: Appris, 2015.

SERRAZINA, Maria de Lurdes. Os materiais e o ensino de Matemática. Revista Educação e Matemática, Lisboa, APM, n. 13, 1990.

TIGGEMANN, Iara Suzana et. al. Geoplanos e redes de pontos: conexões e educação Matemática. Belo Horizonte. Autêntica, 2013. (Série o Professor de Matemática em Ação, v. 4)

VARIZO, Zaira da Cunha Melo; CIVARDI, Jaqueline Araújo. Olhares e Reflexões acerca de Concepções e Práticas no Laboratório de Educação Matemática. Curitiba, PR: CRV, 2011.

ZABALA, Antoni. A Prática educativa: como ensinar. Trad. Ernani F. da F. Rosa. Porto Alegre: ArtMed, 1998.

Recebido em: 5 de maio de 2020.

Aprovado em: 28 de junho de 2020. 